Article

\title{
Production of Microalgal Slow-Release Fertilizer by Valorizing Liquid Agricultural Digestate: Growth Experiments with Tomatoes
}

\author{
Raquel Jimenez $^{1}{ }^{1}$, Giorgos Markou ${ }^{2}$, , Saida Tayibi ${ }^{1,3,4}$, Abdellatif Barakat ${ }^{3,4}$, \\ Camille Chapsal ${ }^{1}$ and Florian Monlau ${ }^{1, *}$ \\ 1 APESA, Plateau Technique, Cap Ecologia, 64230 Lescar, France; rjpri88@gmail.com (R.J.); \\ camille_chapsal@hotmail.fr (C.C.) \\ 2 Institute of Technology of Agricultural Products, Hellenic Agricultural \\ Organization-Demeter (HAO-Demeter), Leof. Sofokli Venizelou 1, Lykovrysi, 14123 Athens, Greece; \\ gmarkou@itap.com.gr \\ 3 IATE, Montpellier University, INRAE, Agro Institut, 34060 Montpellier, France; \\ abdellatif.barakat@inrae.fr (A.B.); saida.tayibi@inrae.fr (S.T.) \\ 4 School of Agriculture, Fertilizing and Environment, Mohammed VI Polytechnic University (UM6P), \\ 43150 Ben Guerir, Morocco \\ * Correspondence: florian.monlau@apesa.fr; Tel.: +33-688-491-845
}

Received: 5 May 2020; Accepted: 27 May 2020; Published: 3 June 2020

\begin{abstract}
Anaerobic Digestion (AD) is a process that is well-known and fast-developing in Europe. AD generates large amounts of digestate, especially in livestock-intensive areas. Digestate has potential environmental issues due to nutrients (such as nitrogen) lixiviation or volatilization. Using liquid digestate as a nutrient source for microalgae growth is considered beneficial because digestate could be valorized and upgraded by the production of an added value product. In this work, microalgal biomass produced using liquid digestate from an agricultural biogas plant was investigated as a slow-release fertilizer in tomatoes. Monoraphidium sp. was first cultivated at different dilutions $(1: 20,1: 30,1: 50)$, in indoor laboratory-scale trials. The optimum dilution factor was determined to be 1:50, with a specific growth rate of $0.13 \mathrm{~d}^{-1}$ and a complete nitrogen removal capacity in 25 days of culture. Then, outdoor experiments were conducted in a $110 \mathrm{dm}^{3}$ vertical, closed photobioreactors (PBRs) in batch and semi-continuous mode with 1:50 diluted liquid digestate. During the batch mode, the microalgae were able to remove almost all $\mathrm{NH}_{4}{ }^{+}$and $65( \pm 13) \%$ of $\mathrm{PO}_{4}{ }^{3-}$, while the microalgal growth rate reached $0.25 \mathrm{~d}^{-1}$. After the batch mode, the cultures were switched to operate under semi-continuously conditions. The cell densities were maintained at $1.3 \times 10^{7}$ cells mL $\mathrm{mL}^{-1}$ and a biomass productivity around $38.3 \mathrm{mg}$ TSS L ${ }^{-1} \mathrm{~d}^{-1}$ during three weeks was achieved, where after that it started to decline due to unfavorable weather conditions. Microalgae biomass was further tested as a fertilizer for tomatoes growth, enhancing by $32 \%$ plant growth in terms of dry biomass compared with the control trials (without fertilization). Similar performances were achieved in tomato growth using synthetic fertilizer or digestate. Finally, the leaching effect in soils columns without plant was tested and after 25 days, only $7 \%$ of $\mathrm{N}$ was leached when microalgae were used, against $50 \%$ in the case of synthetic fertilizer.
\end{abstract}

Keywords: circular economy; growth plant tests; nutrients leaching; nutrients recycling; photo-bioreactor; slow released fertilizer 


\section{Introduction}

Anaerobic digestion (AD) is one of the oldest biological process for the valorization of organic wastes into biogas [1,2]. AD consists of a sequence of processes that involve microorganisms that in the absence of oxygen break organic matter down producing biogas. Over the last decades, digestion capacity in Europe has been increasing rapidly [2]. Many industrial digesters have been built in European countries such as Italy, France, being Germany the largest producer. Anaerobic digestion plants have increased up to 18,202 in 2018 , achieving a production of $63,511 \mathrm{GWh}$ ofbiogas. The main product obtained from $\mathrm{AD}$ is biogas that consists mainly of $50-75 \% \mathrm{CH}_{4}$ and $25-50 \% \mathrm{CO}_{2}$ that can be converted into electricity and heat (Combined Heat and Power plants; $\mathrm{CHP}$ ), injected in the Natural Gas Grid, or used as transportation fuel, whereas the digestate (residues after digestion) typically are used as crop fertilizer and/or soil amendment [3,4].

For a better management of digestates they are often separated into solid and liquid fractions. Solid-liquid separation of digestate presents many advantages, allowing a better management. The solid fraction, which is rich in dry matter, $\mathrm{N}$ and $\mathrm{P}$; is often used as soil amendment to return nutrients back to the fields $[4,5]$. The liquid fraction has been reported to have high contents in $\mathrm{K}$ and $\mathrm{N}$, mainly in its form of ammonia, and it is characterized for a higher N/P ratio than in the solid fraction and generally used as liquid crop fertilizer [5,6].

Nonetheless, large amounts of digestate are currently produced due to the increased number of biogas plants operated, especially in some intensive livestock's area. Digestate engenders some environmental problems related to the greenhouse-gas emissions during storage, its intensive transportation needs $[4,7]$, and due to the leaching or evaporation of nutrients during land application [8,9]. Moreover, the use of digestate on agricultural land is regulated by European EU Directive 91/676/EC, that stablish Nitrate Vulnerable Zones (NVZ) where the annual amount of nitrogen that is applied to the land by spreading does not exceed $170 \mathrm{~kg}$ per hectare. For all these reasons, digestate management has become a major bottleneck of the biogas industry and several alternative digestate valorization routes are under investigation $[4,10,11]$. One promising solution for the recovery of nutrients in the liquid digestate is microalgae cultivation $[8,12,13]$. Indeed, microalgae can efficiently remove the nutrients from digestate while producing high-value biomass that can be used for the production of biochemical, biomaterials, fertilizers and/or biofuels $[12,14,15]$. Since digestates are rich in macronutrients $(\mathrm{N}, \mathrm{P}, \mathrm{K}, \mathrm{S}, \mathrm{Ca}$ and $\mathrm{Mg}$ ) [16-18] and thanks to its ability to uptake nutrients from media, microalgae seem a potential solution to remediate nutrients present in liquid digestate from agricultural biogas plants. For instance, Zuliani et al. (2016) have investigated the cultivation of Chlorella vulgaris on different anaerobic digestates deriving from municipal wastewater, sewage sludge or agro-waste treatment plants in closed photobioreactor [13]. Nonetheless, considering microalgae cultivation on liquid digestate, two major issues should be addressed as the high turbidity of liquid digestate caused by suspended materials and its high ammonia content that can significantly affect the microalgae growth efficiency $[8,11,19]$. Xia and Murphy (2016) reported that concentration of total ammonia nitrogen (TAN) varying from 50 to $260 \mathrm{mg} / \mathrm{L}$ of TAN can inhibit the microalgae growth [11]. For these purposes, two mains strategies that have been investigated in literature data are dilution of the digestate with water $[12,13]$ or liquid digestate treatments to alleviate its toxicity $[8,15,19]$.Until now, diverse technologies of reactors have been used in microalgae cultivation by means of open systems raceway, tubular, column and flat photobioreactors [20], with Chlorella sp. being one of the main microalgae species investigated in literature [12,13,21].

The cultivation of microalgae using Anaerobic Liquid Digestate (ALD) is of particular interest because it provides a production scheme that falls inside the context of a circular bioeconomy, by recycling valuable nutrients and the simultaneously producing of valuable biomass that can be further utilized as a feedstock for a biorefinery platform [17]. However, microalgae cultivated in liquid digestate or wastewaters, which typically contain various hazardous contaminants, and could potentially contaminate the produced biomass, raise various concerns about the safety of their consumption restricting their use for human applications [17]. For this purpose, microalgae used as 
slow-released bio-fertilizers or bio-stimulants have been recently investigated obtaining promising results and can be considered as an eco-friendly solution avoiding chemical pollution especially by leaching or evaporation of nutrients as it happens when synthetic fertilizers or liquid digestate are directly applied in land [22,23].

Besides crops growth efficiency due to the utilization of nutrients, microalgae have also been found to have a biostimuling effect and improving crop yields [22,23]. Microalgae can be applied directly in soil [24-27] or through foliar application [23,25,28]. For instance, Dineshkumar et al. (2018) produced Chlorella vulgaris and Spirulina platensis to employ them as fertilizer in rice growth experiments [29]. As a result, the application with microalgae improved the plant growth rate (in dry weight) by $69 \%$ and $71 \%$ compared to the control (soil alone), respectively for Chlorella vulgaris and Spirulina platensis. Similarly, Garcia-Gonzalez and Sommerfeld (2015) cultivated tomatoes using the microalgal Acuodesmus dimorphus as fertilizer. The application of microalgae as fertilizers enhanced the plant growth rate (shoots + roots) by $50-325 \%$ and by $25-53 \%$ the number of branches in comparison with the associated control [25].

Nonetheless, the application of microalgae as fertilizers for crop production is not yet well studied and more research is needed. Moreover, the use of microalgae cultivated in liquid digestate for slow-released fertilizer is still in its infancy. Thus, in this study, the feasibility of Monoraphidium sp. cultivation in liquid digestate for nutrients remediation coupled with the production of algae-based bio-fertilizers was investigated by means of (1) a preliminary microalgae indoor cultivations tests, where several liquid digestate dilution ratio $(1: 20 ; 1: 30 ; 1: 50)$ where investigated; $(2)$ a pilot-scale outdoor cultivation in column photobioreactors of $110 \mathrm{dm}^{3}$ at the optimal dilution rate; and (3) performing agronomic trials with nutrient leaching columns tests and plant growth pot tests on tomatoes in comparison with synthetic fertilizers and liquid digestate applied at $170 \mathrm{~kg} \mathrm{~N} / \mathrm{ha}$.

\section{Materials and Methods}

\subsection{Microalgae, Soil and Liquid Digestate Origin}

Microscopically identified Monoraphidium sp. was isolated from a lake in Lescar (France) and cultivated in BG-11 medium (Sigma Aldrich) (Dineshkumar et al., 2018). Monoraphidium sp. is a unicellular microalga sizing $2-182 \mu \mathrm{m}$ in length and $1-8 \mu \mathrm{m}$ in width; the cells are straight to lunate to sigmoid or helically twisted, often with elongate ends (https://www.algaebase.org). ALD was obtained from an agricultural biogas plant located in Préchacq-Navarrenx (France), which is operated in mesophilic conditions using as feeding substrates mainly crop residues and animal manure. In this case, the biogas plant separates the digestate into a liquid and solid fraction by a screw press separator. Once collected, the ALD was centrifuged and filtered with a $25 \mu \mathrm{m}$ filter in the laboratory in order to prepare it for further use as a growth medium supplement for microalgae cultivation and was conserved at $3{ }^{\circ} \mathrm{C}$ until its use. The chemical characterization of ALD has been reported in Table 1 . The $\mathrm{pH}\left(25^{\circ} \mathrm{C}\right)$ was of 8.6 and the conductivity of $3640 \mu \mathrm{S} \mathrm{cm}{ }^{-1}$. Zuliani et al. (2016) reported value of $\mathrm{pH}$ varying from 7.6 to 8.2 for digestate of various origin (i.e., municipal wastewater, sewage sludge or agro-waste treatment plants) [13]. For the other parameters, results are in adequation with previous studies that investigated the chemical composition of liquid digestate $[6,9,13]$. The TKN was of $455 \mathrm{~g}$ $\mathrm{N} / \mathrm{kg}$ TS and the ammonium content of $255 \mathrm{~g} \mathrm{~N} / \mathrm{kg}$ representing $56 \%$ of the TKN. Akhiar et al. (2017) reported on several agro-industrial digestates proportion of ammonium ranging from $16 \%$ to $72 \%$ of the TKN [6]. As concerns the heavy metals, higher concentrations were found for $\mathrm{Cu}$ and $\mathrm{Zn}$ with 79.5 and $207 \mathrm{mg} / \mathrm{kg}$ TS respectively and these are generally due to the use of animal slurries in the feeding of the AD plant [9]. Indeed, these two elements are used as additives to stimulate livestock growth and prevent pig and cattle diseases [9]. 
Table 1. Selected chemical properties of the liquid digestate used in this study.

\begin{tabular}{ccc}
\hline Parameters & Values & Units \\
\hline $\mathbf{p H}\left(\mathbf{2 5}{ }^{\circ} \mathbf{C}\right)$ & 8.6 & $\mu \mathrm{cm}^{-1}$ \\
\hline Conductivity & 3640 & $\% \mathrm{raw} \mathrm{matter}$ \\
\hline $\mathbf{T S}$ & 2.0 & $\mathrm{~g} / \mathrm{kg} \mathrm{TS}$ \\
\hline $\mathbf{V S}$ & 470 & $\mathrm{~g} / \mathrm{kg} \mathrm{TS}$ \\
\hline $\mathbf{C O D}$ & 239 & $\mathrm{brut} \mathrm{g} \mathrm{N} / \mathrm{kg} \mathrm{TS}$ \\
\hline $\mathbf{N T K}$ & 216 & $\mathrm{~g} \mathrm{~N} / \mathrm{kg} \mathrm{TS}$ \\
\hline $\mathbf{N H}{ }^{+}$ & 121 & $\mathrm{~g} \mathrm{P} \mathrm{O}_{5} / \mathrm{kg} \mathrm{TS}$ \\
\hline $\mathbf{P}$ & 16.1 & $\mathrm{~g} \mathrm{~K} / \mathrm{O} / \mathrm{kg} \mathrm{TS}$ \\
\hline $\mathbf{K}$ & 252 & $\mathrm{~g} \mathrm{MgO} / \mathrm{kg} \mathrm{TS}$ \\
\hline $\mathbf{M g}$ & 7.1 & $\mathrm{~g} \mathrm{CaO} / \mathrm{kg} \mathrm{TS}$ \\
\hline $\mathbf{C a}$ & 33.8 & $\mathrm{~g} \mathrm{SO} / \mathrm{kg} \mathrm{TS}$ \\
\hline $\mathbf{S}$ & 17.2 & $\mathrm{mg} \mathrm{As} / \mathrm{kg} \mathrm{TS}$ \\
\hline $\mathbf{A s}$ & 2.1 & $\mathrm{mg} \mathrm{Cd} / \mathrm{kg} \mathrm{TS}$ \\
\hline $\mathbf{C d}$ & 0.36 & $\mathrm{mg} \mathrm{Cr} / \mathrm{kg} \mathrm{TS}$ \\
\hline $\mathbf{C r}$ & 5.5 & $\mathrm{mg} \mathrm{Cu} / \mathrm{kg} \mathrm{TS}$ \\
\hline $\mathbf{C u}$ & 79.5 & $\mathrm{mg} \mathrm{Ni} / \mathrm{kg} \mathrm{TS}$ \\
\hline $\mathbf{N i}$ & 10.0 & $\mathrm{mg} \mathrm{Zn} / \mathrm{kg} \mathrm{TS}$ \\
\hline
\end{tabular}

The soil employed for the plant growth tests was obtained from a $10 \mathrm{~cm}$ to $30 \mathrm{~cm}$ layer from a farm located in Montpellier region in France (Inrae from Mauguio). The soil was composed of 20\% of clay, $30 \%$ of sand and $50 \%$ of silt. Air-dried soil was sieved $(<4 \mathrm{~mm})$ and stored $\left(15^{\circ} \mathrm{C}\right)$ until the beginning of the experiments. The soil was composed of organic matter $(1.9 \%), \mathrm{C} / \mathrm{N}$ ratio (10.1), $\mathrm{pH}$ (7.4), total nitrogen $(0.11 \%), \mathrm{P}_{2} \mathrm{O}_{5}(0.096 \mathrm{~g} / \mathrm{kg}), \mathrm{K}_{2} \mathrm{O}(0.386 \mathrm{~g} / \mathrm{kg})$ and $\mathrm{MgO}(0.195 \mathrm{~g} / \mathrm{kg})$.

\subsection{Indoor Batch Cultivation of Microalgae Testing Various Digestate Dilution}

The purpose of these experiments was to evaluate the algal growth performances at different dilution rates of ALD. Dilution of ALD was considered as a necessary step in order to alleviate its toxicity due to high ammonium and turbidity content $[8,19]$. a seeding of these cultures was carried out on ALD at different dilution concentrations (dilution of 1:20, 1:30 and 1:50 using distilled water). The culture was carried out on a laboratory scale, in a growth shelf, using 2- $\mathrm{dm}^{3}$ bottles (cf. Figure S1). Cells were inoculated into the medium at a proportion of $20 \%(v / v)$. Each batch was performed in duplicate and started from an initial algae biomass concentration of $0.14 \mathrm{gTSS} \mathrm{L}^{-1}$. The cultures were artificially illuminated $\left(33.75 \mu \mathrm{mol} \mathrm{m} \mathrm{m}^{2}\right)$ and bubbled with a mix of air and carbon dioxide $\left(0.2 \% \mathrm{v}_{\mathrm{CO} 2} / \mathrm{v}_{\text {air }}\right)$ controlled by a mass flow meter from Aalborg ${ }^{\circledR}$. Temperature was kept at room values $\left(21-23^{\circ} \mathrm{C}\right)$. Irradiance was provided by warm-white fluorescent lamps. The light intensity was measured from the outer surface of the crystal bottles using a LX-105 Digital Light LUX meter RS232 and then converted

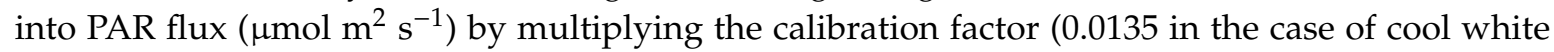
fluorescent lamps). Microalgae growth was daily followed by determining Optical Density (OD) at $680 \mathrm{~nm}$ with a UV-visible spectrometer (7315, Jenway, United Kingdom), after proper dilution with deionized water to obtain absorbance values between zero and one.

The specific growth rate in the exponential phase of the algal growth was measured using Equation (1).

$$
\mu\left(\text { day }^{-1}\right)=\left(\operatorname{Ln} X_{2}-\operatorname{Ln} X_{1}\right) /\left(t_{1}-t_{2}\right)
$$


where $X_{2}$ and $X_{1}$ are the Cell numbers (Cells $\left./ \mu \mathrm{L}\right)$ at time $t_{2}$ and $t_{1}$, respectively.

In parallel, the nutrient removal efficiency was also calculated according the Equation (2) below:

$$
\operatorname{NRE}(\%)=100-\left(100 * \mathrm{Ct} / \mathrm{C}_{\mathrm{o}}\right)
$$

where $C_{o}$ and $C_{t}$ are the nutrient concentrations $(\mathrm{mg} / \mathrm{L})$ at the beginning of the experiment and end of the experiment respectively.

\subsection{Outdoor Photo-Bioreactors Cultivation of Microalgae on the Best Dilution Ratio}

The best dilution ratio (1:50) obtained in the first screening tests was further applied for microalgae cultivation in outdoor condition to be the most representative of further industrial-scale. For this purpose, Monoraphidium sp. was cultivated outdoors, between August and November 2019, in a $110 \mathrm{dm}^{3}(0.29 \mathrm{~m} \times 1.65 \mathrm{~m})$ vertical closed photobioreactors with an active volume of $73 \mathrm{dm}^{3}$ located in Lescar (France) (Figure 1 and Figure S2). Tap water was used to formulate the culture medium, where ALD was used as nutrients source at a dilution ratio of 1:50. The first batch started with an initial algae biomass concentration of $0.12 \mathrm{gTSS} / \mathrm{L}$. The culture was bubbled with air and the $\mathrm{pH}$ maintained within a desired range ( $\mathrm{pH} 7.3-8.1$, with a set point of 7.7) to support algae growth. The $\mathrm{pH}$ was controlled by a $\mathrm{pH}$ meter and was regulated by $\mathrm{CO}_{2}$ injection in the system through a solenoid valve. When the $\mathrm{pH}$ reached the set point (7.7), the controller opened the valve to allow $\mathrm{CO}_{2}$ injection, so that $\mathrm{CO}_{2}$ reduces pH level.

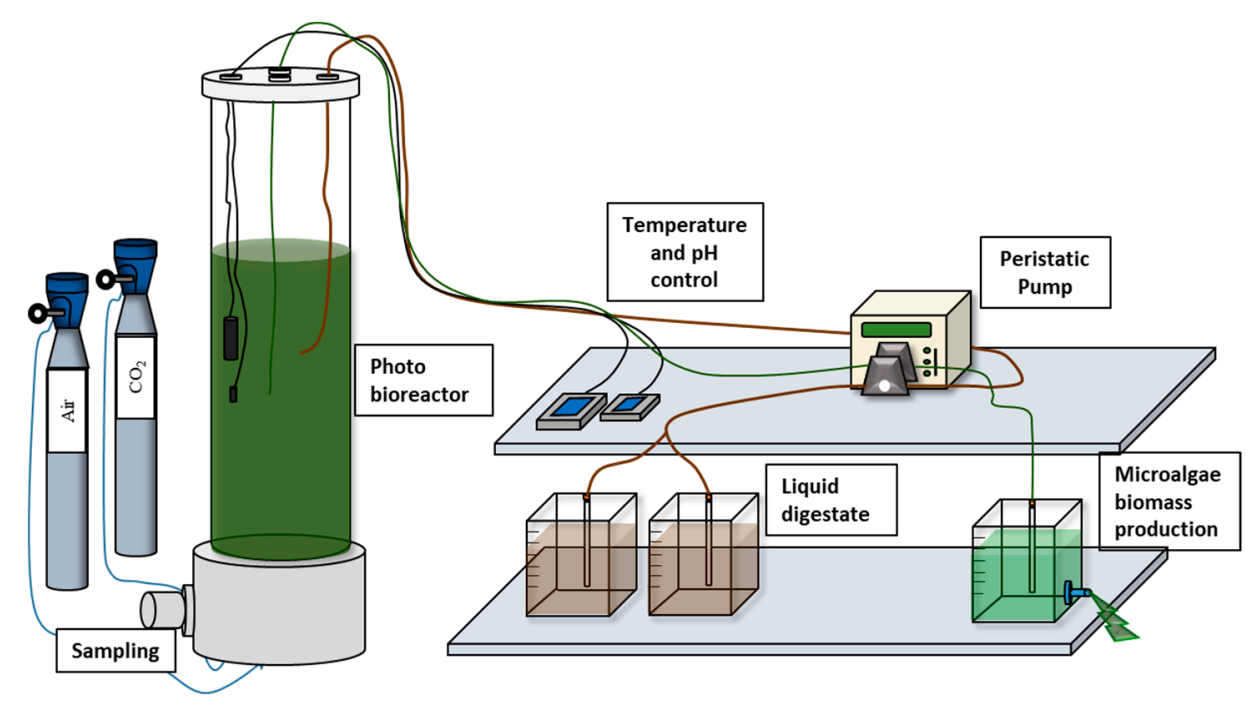

Figure 1. Scheme of experimental set up for microalgae production in semi-continuous mode in outdoor conditions in the vertical closed photobioreactors.

First, three experiments in batch mode were carried out in order to optimize the photo-bioreactor performance and to define the optimal retention time. Once the system was optimized, the culture was switched to semi-continuous mode which lasted from September to November 2019. The retention time applied was 15 days and the feeding of ALD was performed using a peristatic pump (Figure 1). Climatological data in Lescar region were extracted from the website of "Meteo France" (http://www.meteofrance.com/accueil).

Microalgae growth was daily monitored by determining Optical Density (OD) at $680 \mathrm{~nm}$ with a UV-visible spectrometer (7315, Jenway, United Kingdom), after proper dilution with deionized water to obtain absorbance values between zero and one. In parallel, the microalgae growth was measured by counting cells system using Malassez method (Absher, M. 1973, Blaubrand ${ }^{\circledR}$, Germany). Briefly, Malassez method consists of a thick glass microscope slide (Malassez) with a rectangular indentation 
that creates a chamber of a well-known volume, so the number of contained cells can be determined. Light microscopy was carried out using a Zeiss Axioskop 2 equipped with an AxioCam MRc camera.

Total suspended solids (TSS) were measured by filtering $5-15 \mathrm{~mL}$ culture solution through a glass fiber filter (Whatman GF/A). TSS was determined gravimetrically as a difference of the filters before and after drying at $105^{\circ} \mathrm{C}$ for $24 \mathrm{~h}$.

The microalgae biomass was harvested during the semi-continuous phase by drying it at $70{ }^{\circ} \mathrm{C}$, and it was then conserved at room temperature in a dry container. The Equation (3) was applied in order to calculate the biomass productivity $(\mathrm{P})$ :

$$
P=\left(D W_{i}-D W_{0}\right) /\left(t_{i}-t_{0}\right)
$$

where $D W_{i}$ and $D W_{0}$ are the Dry Weights $\left(\mathrm{gTSS} \mathrm{L}^{-1}\right)$ at time $t_{i}$ and $t_{0}$ (initial time), respectively.

\subsection{Physicochemical Analysis}

The culture $\mathrm{pH}$ was measured using a VWR $\mathrm{pHenomenal}{ }^{\circledR} \mathrm{pH}$ portable set $\mathrm{pH} 1100 \mathrm{H}$. Each filter, containing the suspended solids, was dried at $105^{\circ} \mathrm{C}$ overnight and then weighed. Nitrogen and phosphorus consumption were analyzed during the trial by spectrophotometry. The analyses were accomplished by centrifuging the samples at $5000 \mathrm{rpm}$ during $15 \mathrm{~min}$ in a centrifuge (Rotanta 460, Hettich Centrifuges, United Kingdom). The supernatant was analyzed with Spectroquant cell tests, specific for each nutrient. In all cases, the nutrients concentration was measured by a photometer PhotoLab S6 WTW. The elemental composition of the produced microalgal biomass (C, H, N, S) was analyzed in duplicate using an elemental analyzer (varioMicro V4.0.2, Elementar ${ }^{\circledR}$, Germany). Microand macro-elements analysis were performed by digesting $38.5 \mathrm{mg}$ of sample in $2 \mathrm{~mL}$ of $\mathrm{HNO}_{3}(68 \%)$ and $5 \mathrm{~mL}$ of distilled water, in a closed vessel microwave digester. The solutions were analyzed by inductively coupling plasma spectrometry-optical emission spectroscopy (ICP-OES Agilent 720).

\subsection{Agronomic Trials on Microalgae Biomass}

The agronomic value of microalgal biomass produced in the photo-bioreactor was investigated through phytotoxicity tests and nutrients leaching tests in columns in comparison with liquid digestate and synthetic fertilizers. Plants trials with seeds of tomatoes (Solanum Lycopersicum) were performed in small pots with a volume of $0.5 \mathrm{dm}^{3}$, placed in a standard growth chamber (Fitotron, SGC 120 Weiss Gallenkamp, United Kingdom) under controlled conditions. During the trials, the environmental conditions were the following ones: day duration $16 \mathrm{~h}$ at $25^{\circ} \mathrm{C}$ under $4600 \mathrm{lux}\left(62.1 \mu \mathrm{mol} \mathrm{m}^{2} \mathrm{~s}^{-1}\right)$, in $60 \%$ relative humidity, whereas night conditions were $8 \mathrm{~h}$ darkness at $18{ }^{\circ} \mathrm{C}$ in $80 \%$ relative humidity. Four conditions were tested: (1) soil alone (control), (2) soil + synthetic fertilizers, (3) soil + digestate and (4) soil + dried microalgal biomass. a dose of $170 \mathrm{~kg} \mathrm{~N} / \mathrm{ha}$ was applied for the three last trials, according to the limits stablished by EU regulations for land application of fertilizers near watercourses (EU Directive 91/676/EC). For synthetic fertilizer, $\mathrm{N}$ sources was provided by ammonium nitrate. For $\mathrm{P}$ dosage of synthetic fertilizers, monopotassium phosphate was applied at $22 \mathrm{~kg} \mathrm{P} / \mathrm{ha}$, same proportion than in liquid digestate. Such doses are within the range of $\mathrm{N}$ and $\mathrm{P}$ application rates for different crops systems [30]. The mixtures of soil and fertilizers sources were prepared into $10 \mathrm{~cm}$ diameter plastic pots and the mixture was brought to $70 \%$ of the water holding gravimetric capacity. Six tomato seeds were planted in each pot using four replicates for each condition. Each pot was manually watered every 24 $\mathrm{h}$ by weighing and adding water to achieve the initial weight. Once $70 \%$ of control seeds germination was obtained, four seeds of tomatoes were let in each pot, to make space for the plants to growth during the first vegetative stage. After 47 days, the leaves of each plant were counted before being harvested by cutting them at the soil level. Then, the biomass was dried for $48 \mathrm{~h}$ at $70^{\circ} \mathrm{C}$ in a forced air 
oven, and finally weighted. For each condition, germination index (expressed in percent) of the initial seeds and biomass dry matter were measured and calculated as follows (Equations (4) and (5)):

$$
\begin{gathered}
\text { Germination Index }(\%)=\frac{\text { Final number of seeds that germinated }}{\text { Number of initial seeds }} \times 100 \\
\text { Dry weight }(g T S / 100 \text { plants })=\frac{\text { Dry weight of harvested plants }(70 \mathrm{C})}{\text { Number of plants }} \times 100
\end{gathered}
$$

Analysis of variance (ANOVA) was carried out to compare variables means. The results of plant growth were analyzed to classify the significant differences compared to the control (i.e., soil alone), the confidence level considered was $95 \%$. Elementary analysis (C, H, N, S) have been determined using an elemental analyzer (varioMicro V4.0.2, Elementar ${ }^{\circledR}$, Germany). The method employed for determination of Chlorophyll a, Chlorophyll $b$ and carotenoids was adapted from the one used by [31]. Accurately weighted $0.5 \mathrm{~g}$ of fresh plant leaf sample was homogenized with $10 \mathrm{~mL}$ of methanol. The mixture was centrifuged $8000 \mathrm{rpm}$ for $20 \mathrm{~min}$ (Rotanta 460, Hettich Centrifuges, United Kingdom). The supernatant was separated and $0.5 \mathrm{~mL}$ of it was mixed with $4.5 \mathrm{~mL}$ of methanol. The solution was analyzed in a spectrophotometer (7315, Jenway, United Kingdom). Equations to determine concentrations $\left(\mu \mathrm{g} \mathrm{ml}^{-1}\right.$ ) of chlorophyll a (Ch a), chlorophyll b $(\mathrm{Ch} \mathrm{b})$ and total carotenoids $(\mathrm{Ca})$ by methanol as solvent are as follows:

$$
\begin{gathered}
\text { Ch } a=16.72 A_{665}-9.16 A_{652} \\
\text { Ch } b=34.09 A_{652}-15.28 A_{665} \\
C a=\left(1000 A_{470}-1.63 \text { Ch } a-104.96 \text { Ch } b\right) / 221
\end{gathered}
$$

A method adapted from [32], was used to carry out leaching nutrients without plants. This study was intended to represent a worst-case scenario with extremely heavy rainfall just after adding the different fertilizers [33]. The leaching columns were designed using a $50 \mathrm{~mL}$ plastipak medical syringe (with the piston removed). Each column was fixed with filter papers (glass microfiber filter GF/F, diameter $25 \mathrm{~mm}$ ), and each contained $15 \mathrm{~g}$ of quartz sand. Then, $20 \mathrm{~g}$ of each soil mixture was added including the four conditions: (1) soil alone (control), (2) soil + synthetic fertilizers, (3) soil + liquid digestate and (4) soil + dried microalgae biomass. The top of each column was also covered with parafilm in order to avoid water evaporation. Finally, $20 \mathrm{~g}$ of quartz sand was used to fill the soil columns to the top to avoid soil disturbance during leaching. Each treatment was replicated three times and fertilizers were applied as a rate of $170 \mathrm{~kg} \mathrm{~N} / \mathrm{ha}$. After, deionized water was added to the soil columns to obtain $100 \%$ of water holding capacity (WHC), then, the columns were incubated at $20^{\circ} \mathrm{C}$. After 3, 6, 12, 18, 25 days, $20 \mathrm{~mL}$ of deionized water was added to the top of columns corresponding to $450 \mathrm{~mm}$ of precipitation during a 25 days period. Then the leachate volume was recorded (after approximately $7 \mathrm{~h}$ ). The cations $\left(\mathrm{NH}_{4}{ }^{+}\right)$and anions $\left(\mathrm{NO}_{3}{ }^{-}, \mathrm{NO}_{2}{ }^{-}\right)$concentrations in the leachate were measured by an ICS-3000 Ion Chromatography System after centrifugation of the digestate in 2-mL Eppendorf ${ }^{\circledR}$ tubes, followed by filtration at $0.2 \mu \mathrm{m}$ (Nylon membrane, Acrodisc ${ }^{\circledR}$ ).

\section{Results and Discussions}

\subsection{Impact of Liquid-Digestate Dilution on Microalgae Growth on Batch Conditions}

Microalgae growth was tested by using three different digestate dilution $(1: 20 ; 1: 30 ; 1: 50)$ as culture media. The optimum dilution factor of the digestate was studied in batch mode in indoor condition in order to determine its feasibility as nutrient supplier for microalgae growth. Growth characteristics of Monoraphidium sp. cultivated in digestate diluted 1:20, 1:30 and 1:50 where investigated within 25 days as shown in Figure 2. As a result, specific growth of $0.03,0.05$ and $0.13 \mathrm{~d}^{-1}$ were calculated for digestate dilutions of L 20, L 30 and L 50 respectively (Figure 2a). In the case of low diluted digestate (L 20), the 
microalgae growth noticeable decelerated after 12 days, due to probably the high turbidity and the high initial ammonium concentration $\left(98.8 \mathrm{mg} \mathrm{L}^{-1}\right)$, which can presents toxicity for microalgae cells $[11,19]$. Dhup et al. (2014) reported similar specific growth rate ranging from 0.05 and $0.09 \mathrm{~d}^{-1}$ when the microalgae Monoraphidium sp. T4X was cultivated under six different nitrate concentration [34]. Our results and dilution rate applied are quite lower to previous studies that investigated microalgae growth on diluted digestate but using different microalgae species [12,13,35]. Franchino et al. (2013) have investigated the cultivation of three microalgae strains (Neochloris oleoabundans, Chlorella vulgaris and Scenedesmus obliquus) on an agro-zootechnical digestate at different dilution ratios (1:10; 1:15; 1:20: 1:25) [12]. At a dilution rate of $1: 20$, specific growth rate of $0.26,0.23,0.49 \mathrm{~d}^{-1}$ were respectively observed for Neochloris oleoabundans, Scenedesmus obliquus and Chlorella vulgaris [12]. Uggetti et al. (2014) reported value of growth rate for Scenedesmus sp. ranging from 0.04 to $0.9 \mathrm{~d}^{-1}$ at different inoculum/substrate ratio [35]. The dilution ratio that should be applied to improve microalgae growth by minimizing ammonia and turbidity toxicity is highly dependent on the liquid digestate nature and origin but value from literature are ranging from 1:10 until 1:100 [12,19,36]. To improve the overall environmental and economic feasibility of the process, it can be planned as future works to replace part of the tap water by agro-industrial wastewaters to reduce the ALD turbidity.

a)

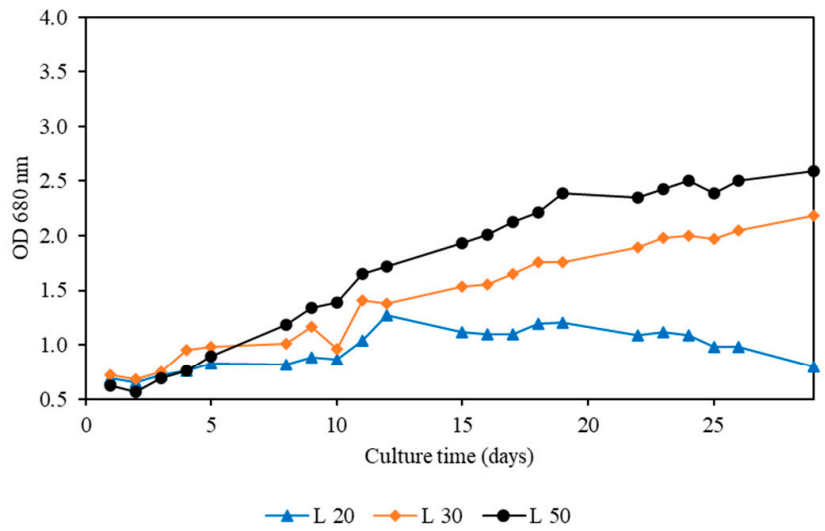

b)

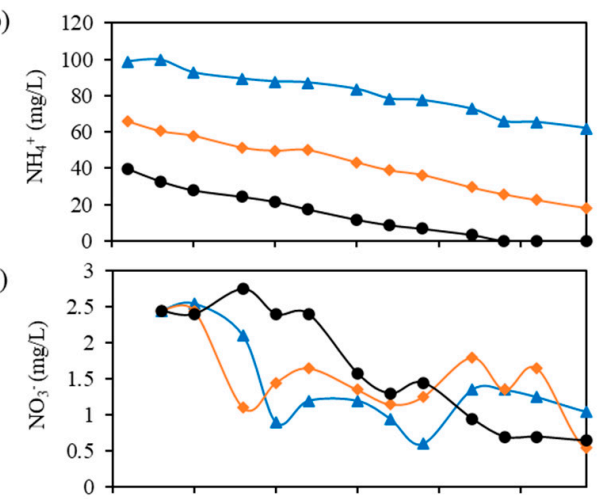

d)

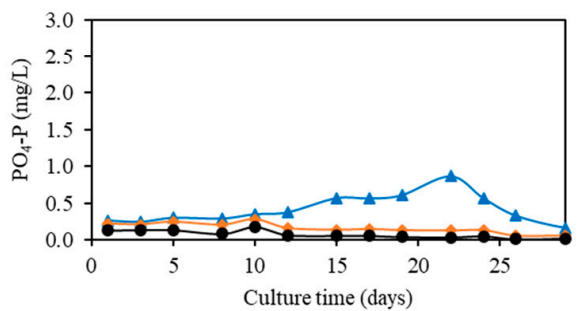

Figure 2. (a) Growth curves and (b) $\mathrm{NH}_{4}{ }^{+}$, (c) $\mathrm{NO}_{3}{ }^{-}$and (d) $\mathrm{PO}_{4}{ }^{3-}$ consumption for Monoraphidium sp. cultivated in digestate diluted at 1:20 (L 20), 1:30 (L30) and 1:50 (L 50).

The batch with higher dilution has better response to nutrients assimilation; therefore, microalgae growth is more feasible. After 25 days, 34, 66 and $100 \%$ of $\mathrm{NH}_{4}{ }^{+}$were removed from media, from less to more diluted digestate respectively (Table 2). Similarly, P removal of 0,77 and $92 \%$ were observed from less to more diluted digestate respectively. Nutrient removal efficiency for $\mathrm{N}$ and $\mathrm{P}$ is in agreement with previous studies that investigated microalgae growth on diluted digestate [12,19]. At day 19, the culture with the lowest dilution collapsed and was not able to assimilate more nutrients (Figure 2c,d). 
Table 2. Main microalgae performances parameters and nutrients removal efficiency (\%) for the culture lead in batch in indoor condition at various dilution rate of 1:20; 1:30; 1:50 and outdoor condition (B1, B2 and B3) at a dilution rate of 1:50. B1, B2 and B3 represent the three successive batches lead in outdoor condition prior to the semi-continuous assay.

\begin{tabular}{|c|c|c|c|c|c|c|}
\hline & \multicolumn{3}{|c|}{ Indoor } & \multicolumn{3}{|c|}{ Outdoor } \\
\hline & L 20 & L 30 & L 50 & B1 & B2 & B3 \\
\hline Specific growth, $\mu\left(\mathrm{d}^{-1}\right)$ & 0.03 & 0.05 & 0.13 & 0.25 & 0.14 & 0.21 \\
\hline $\begin{array}{c}\text { Biomass productivity (mg } \\
\text { TSS L }^{-1} \mathrm{~d}^{-1} \text { ) }\end{array}$ & - & - & - & 43.3 & 31.7 & 39.8 \\
\hline Cells $\max \left({ }^{*} 10^{7}\right.$ cell $\left./ \mathrm{mL}\right)$ & 0.74 & 2.2 & 3.6 & 1.7 & 1.3 & 1.6 \\
\hline Biomass yield (g TSS. $\mathrm{L}^{-1}$ ) & - & - & - & 0.77 & 0.57 & 0.68 \\
\hline $\mathrm{NH}_{4}+(\%$ removal capacity $)$ & 34 & 66 & 100 & 100 & 100 & 100 \\
\hline $\mathrm{P}_{-} \mathrm{PO}_{4}{ }^{-3}$ (\%removal capacity) & 0 & 77 & 92 & 78.5 & 46.6 & 75.6 \\
\hline
\end{tabular}

\subsection{Cultivation of Microalgae in Outdoor Conditions}

To validate the scenario observed in batch indoor conditions, outdoor microalgae growth was also investigated in photobioreactor of $110 \mathrm{dm}^{3}$ applying a liquid digestate dilution 1:50 (Figure S2). Two basic cultivation regimes were investigated as batch and semi-continuous regime. In the batch regime, the culture was inoculated and at a certain point of growth was harvested. In the continuous regime, the culture was harvested continuously according to its growth rate and fresh medium was added [37]. Figure 3 a shows the temperature and sunlight hours registered during cultivation time of Monoraphidium sp. for a better understanding of the microalgae-growth behavior and nutrients removal from the media. For the batch mode trials, the temperature ranged from $14{ }^{\circ} \mathrm{C}$ to $25^{\circ} \mathrm{C}$ and the average sun exposition from 5 to $10 \mathrm{~h}$. During the semi-continuous trials, meteorological conditions for the three first weeks were similar to batches but further degraded with temperature ranging from 8 ${ }^{\circ} \mathrm{C}$ to $13^{\circ} \mathrm{C}$ and an average sun exposition of only $2 \mathrm{~h}$.

Interestingly, the specific growth rate for the outdoor batches was higher than in indoor conditions with specific growth rate of $0.25,0.14$ and $0.21 \mathrm{~d}^{-1}$ respectively for B1, B2 and B3 (Figure 3b, Table 2). Biomass productivity of $43.3 ; 31.7$ and $39.8 \mathrm{mg} \mathrm{TSS} \mathrm{L}^{-1} \mathrm{~d}^{-1}$ were obtained for respectively B1, B2 and B3. At steady growth, biomass yields of $0.77,0.57$ and $0.68 \mathrm{~g} \mathrm{TSS.L^{-1 }}$ where respectively achieved for the B1, B2 and B3 batches. It is most probably that the higher specific growth rates obtained in outdoor compared to the indoor conditions was due probably to the higher light illumination (Table 2). During the three batches, microalgae outdoor cultivation demonstrated high nutrient-removal capacity

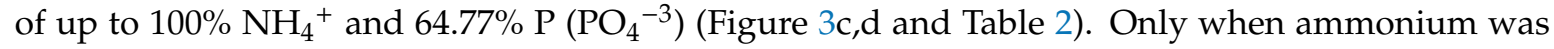
exhausted, did nitrates start to be consumed, as indicated in Figure 3c. Nitrogen is assimilated by the cells in different forms; ammonium $\left(\mathrm{NH}_{4}{ }^{+}\right)$and nitrates $\left(\mathrm{NO}_{3}{ }^{-}\right)$, being ammonium the preferred as a nitrogen source [18]. In less amount, phosphorus also played an important role, as it constitutes important molecules for microalgae growth $[11,18,38]$. Once the third batch was completed, the system was shifted in a semi-continuous mode. During three weeks of operation the microalgal performances remained stable with cell densities in the level at $1.3 \times 10^{7}$ cells $\mathrm{mL}^{-1}$. Then, the microalgae growth started to decline because of the unfavorable meteorological conditions. 
a)

b)

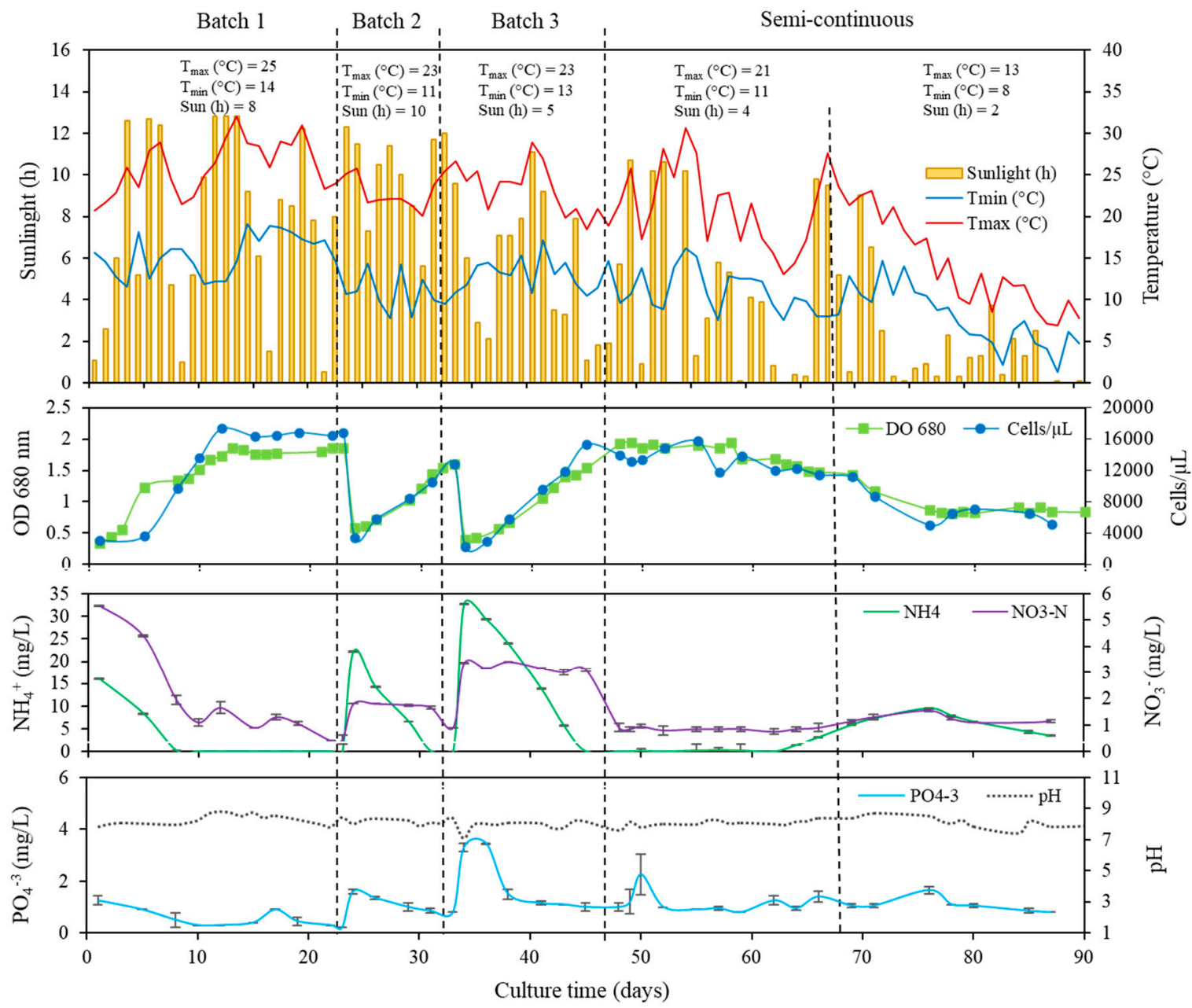

Figure 3. (a) Weather condition and temperature data graphs during the running period of the photobioreactor, (b) Monoraphidium sp. growth curves in liquid digestate diluted at 1:50, expressed in absorbance at $680 \mathrm{~nm}$ and number of cells per $\mu \mathrm{L}$, (c) $\mathrm{NH}_{4}{ }^{+}$and $\mathrm{NO}_{3}{ }^{-}$consumption expressed in $\mathrm{mg}$ $\mathrm{L}^{-1}$, (d) $\mathrm{pH}$ and $\mathrm{PO}_{4}{ }^{3-}$ consumption expressed in $\mathrm{mg} \mathrm{L}^{-1}$. Results are presented for photo-bioreactors for the three batches (B1, B2, B3) and semi-continuous trials.

Several other studies have reported microalgae cultivation in outdoor conditions [21,39,40]. First of all, Rezanka et al. (2017) have investigated the cultivation of the Monoraphidium sp. CCALA 1094 microalgae strain in synthetic medium in outdoor $150 \mathrm{~L}$ thin-layer photobioreactor under early winter conditions of Central Europe [40]. The specific growth rate over the 22 days of the pilot cultivation reached a value of $0.341 \mathrm{~d}^{-1}$ which is in the same range as the results of the present study [40]. Similarly, Chlorella sp. was cultivated in digestate (non-diluted) by conducting an outdoors experiment in an open pond semi-continuously for 37 days. With natural light in the range between $215-700 \mu$ mol photons $\mathrm{m}^{2}$ $\mathrm{s}^{-1}$ and $0-25^{\circ} \mathrm{C}$, a productivity of $17.4 \mathrm{mg} \mathrm{L}^{-1} \mathrm{~d}^{-1}$ of microalgae biomass was obtained [21]. Similarly, Prajapati et al., (2014) reported biomass yield of $0.79 \mathrm{~g} \mathrm{TSS}^{-1}$ when the microalgae Chroococcus sp. was cultivated on diluted digestate by 1:30 [36]. Barreiro-Vescovo et al. (2020) also investigated a microalgae consortium in outdoor batch and semi-continuous experiments in a $4.5 \mathrm{~m}^{2}$ raceway pond in summer and early autumn seasons on OFMSW liquid digestate fraction diluted at 1:20 for the batch mode and 1:10 for the semi-continuous mode [41]. From day 0 to 35, the biomass concentration and productivity increased until a maximum value of $0.74 \mathrm{~g}^{\text {TSS L }} \mathrm{L}^{-1}$ and $6.9 \mathrm{~g} \mathrm{TSS} \mathrm{m}^{2} \mathrm{~d}^{-1}$. After day 35, the concentration of TSS started to decrease until minimum values close to $0.13-0.31 \mathrm{~g}$ TSS $\mathrm{L}^{-1}$ corresponding to productivity values of 1.2-2.9 $\mathrm{g} \mathrm{TSS} \mathrm{m}^{2} \mathrm{~d}^{-1}$ [41]. Finally Marin et al. (2018) investigated seasonal variation of biogas upgrading coupled with digestate treatment in outdoors 
raceway ponds on a microalgae consortium [39]. In this study, process operation was carried out from 1 November 2016 to 30 October 2017. Areal biomass productivity ranged from $0.0 \mathrm{~g} \mathrm{TSS} \mathrm{m}^{-2} \mathrm{~d}^{-1}$ in winter to $22.5 \mathrm{~g} \mathrm{TSS} \mathrm{m}^{-2} \mathrm{~d}^{-1}$ in summer [39].

The elemental composition of the produced biomass of Monoraphidium sp. was $30.62 \pm 0.22 \%$ C, $4.04 \pm 0.03 \% \mathrm{H}, 3.27 \pm 0.26 \% \mathrm{~N}$ and $0.85 \pm 0.02 \% \mathrm{~S}$ (Table 3). Low carbon and nitrogen content was reported in the microalgae compared with the results of other authors [42,43]. Lower carbon and nitrogen concentration can be explained by the higher ash content from microalgae but also from mineral residual faction of the digestate as the overall microalgae medium was oven dried. Microalgae was also composed of other nutrients $(\mathrm{K}, \mathrm{P}, \mathrm{Ca}, \mathrm{Mg})$ which are reported in Table 3.

Table 3. Main chemical properties of the microalgae cultivated and harvested in this study.

\begin{tabular}{cc}
\hline Parameters & Values \pm S.D) \\
\hline C (\% TS) & $30.62 \pm 0.22$ \\
\hline H (\% TS) & $4.04 \pm 0.03$ \\
\hline N (\% TS) & $3.27 \pm 0.26$ \\
\hline S (\% TS) & $0.85 \pm 0.02$ \\
\hline K(\% TS) & $0.55 \pm 0.02$ \\
\hline P(\% TS) & $0.90 \pm 0.2$ \\
\hline Ca (\% TS) & $0.45 \pm 0.02$ \\
\hline $\mathbf{M g}(\%$ TS) & $0.25 \pm 0.08$ \\
\hline
\end{tabular}

\subsection{Agronomic Trials by Plant Growth and Lixiviation Tests}

The results of Germination Index (GI) (Figure 4a and Table 4) showed that in the trials with soil (without any treatment) GI reached 100\% whereas values of 96,79 and $92 \%$ were obtained for pots amended with synthetic fertilizer, digestate and microalgae biomass respectively. However, according to the ANOVA test, no statistically significant differences were obtained. The slight drop in GI for the digestate samples can be explain by some soluble compounds (VFAs, ammonium, trace elements) that might inhibit the germination $[3,44,45]$ In general rules, from literature data, no negative effect on germination were observed from digestate at high dilution rate, while high concentrations showed germination inhibition [3,44]. Then, the impact of the three fertilizations (i.e., synthetic fertilizers, liquid digestate, microalgae added at $170 \mathrm{~kg} \mathrm{~N} / \mathrm{ha}$ ) is shown in Figure 4a. Plant dried biomass was 24.8 $\pm 0.8,25.1 \pm 2.5$ and $25.6 \pm 1.2 \mathrm{~g} \mathrm{TS} / 100$ plants for respectively synthetic fertilizers, liquid digestate and microalgae showing similar efficiency between microalgae and synthetic fertilizers for same $\mathrm{N}$ supply. In other words, microalgae bio-fertilizer enhanced tomato growth by $32 \%$ in terms of total plant dried biomass compared to the control (i.e., soil without any fertilizer). Similarly, synthetic fertilizers and liquid digestate lead to $27 \%$ and $29 \%$ enhancement of the plant dried biomass in comparison to the soil control. Such results demonstrate that microalgae were as effective for growth tomatoes as other fertilizer sources during the first vegetative growth stage (ANOVA $p<0.05$ ). Similarly, in the case of leaves number (Figure 4b), 45, 43 and 32\% more leaves were found in plants amended with synthetic fertilizer, digestate and microalgae biomass, respectively in comparison with the control tests (soil without fertilization) which it is also an indication of the plant health. Finally, in terms of pigments content (i.e., chlorophyll and carotenoids) (Figure 4c), adding microalgae biomass improved the pigments contents compared to the control trials (without fertilization) but the enhancement was lower compared to the synthetic fertilizer and liquid digestate application. This is probably due to a reduction in the absorption of nutrients needed for chlorophyll production by the plants, especially mineral nitrogen. Contrary to synthetic fertilizers and liquid digestate, nitrogen is available in microalgae in the form of organic nitrogen and should be mineralized before to be used by plants. Likewise, Mulbry et al. (2005) found that only around 3\% of the biomass $\mathrm{N}$ was available as mineral $\mathrm{N}$ at the time of application and approximately $33 \%$ of algal $\mathrm{N}$ was converted to plant-available $\mathrm{N}$ within 21 days [26]. 
a)

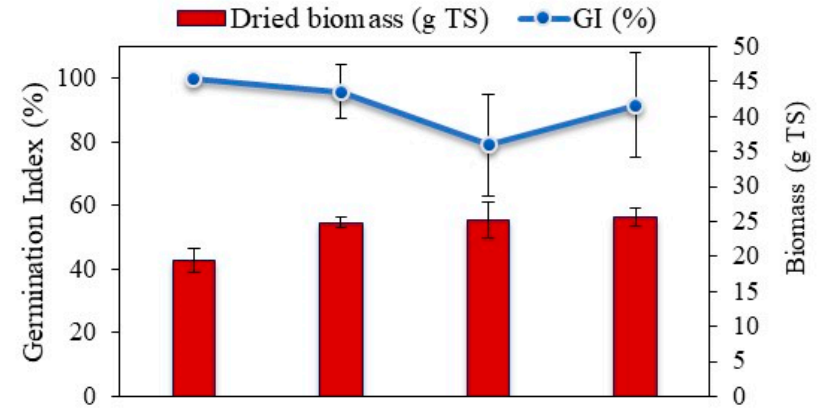

b)

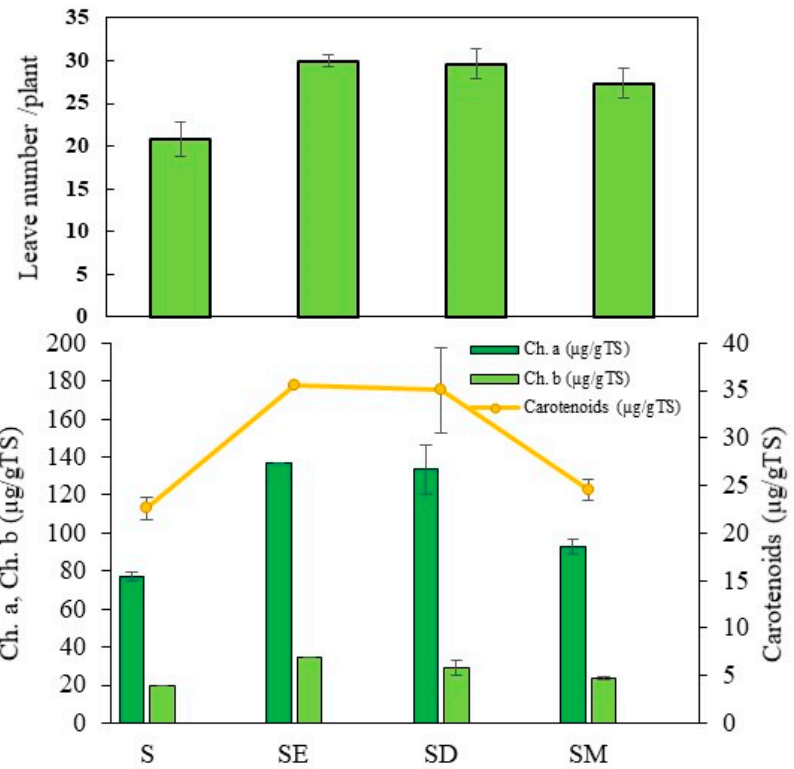

Figure 4. (a) Germination Index (GI) and dried biomass, (b) leaves numbers and (c) chlorophyll and carotenoids contains obtained in tomato plant grown with the following conditions: $\mathrm{S}$ (soil alone, control), SE (soil + synthetic fertilizer), SD (soil + liquid digestate) and SM (soil + microalgal biomass).

Table 4. Elemental composition of tomato plants cultivated in the following conditions: with no fertilizer (S), synthetic fertilizer (SE), liquid digestate (SD) and microalgal biomass (SM). Given values $( \pm S . D)$.

\begin{tabular}{ccccc}
\hline & C (\% TS) & H (\% TS) & N (\% TS) & S (\% TS) \\
\hline S & $38.60 \pm 0.12$ & $5.94 \pm 0.06$ & $0.95 \pm 0.03$ & $0.26 \pm 0.01$ \\
\hline SE & $38.13 \pm 0.14$ & $5.88 \pm 0.01$ & $1.54 \pm 0.03$ & $0.21 \pm 0.00$ \\
\hline SD & $37.76 \pm 0.03$ & $5.87 \pm 0.03$ & $1.45 \pm 0.03$ & $0.28 \pm 0.01$ \\
\hline SM & $38.14 \pm 0.14$ & $5.88 \pm 0.06$ & $1.04 \pm 0.01$ & $0.33 \pm 0.02$ \\
\hline
\end{tabular}

The elemental composition of the tomato plants grown in different conditions is given in Table 4 . Similar C content were found for all the conditions. The most noticeable results were observed for nitrogen in the plants cultivated in soil alone (control) and microalgae fertilizers, where $\mathrm{N}$ content was lower than those found in the composition of tomato plants cultivated in the synthetic fertilizers and liquid digestate.

The benefits of using liquid digestate or microalgae to enhance growth plant tests have been previously demonstrated to be as efficient as synthetic fertilizers [26,30]. Table 5 shows different studies from literature data that used microalgal biomass as fertilizer for plants growth. Microalgae has been used as fertilizers for the cultivation of various plants and vegetables such as: tomatoes [25,43], millet crops [46], corn [26,27], lettuce [24], cucumber [26], arugula [47] and bayam red [47]. Nonetheless, only one study until yet have reported the use of microalgae cultivated in liquid digestate from biogas plant 
to be used as fertilizers. In this study, Mulbry et al. (2005) investigated the use of an algal consortium to be used for the cultivation of cucumber and corn plants [26]. For the two plants investigated, algae used as fertilizers lead to an enhancement of the growth plant in comparison with no fertilization and similar results were observed between microalgae and synthetic fertilizers [26]. Wuang et al. (2016) studied the potential of cultivating Spirulina platensis with fish wastewater for production of algae fertilizers [47]. Spirulina-based fertilizers demonstrated to enhance plant growth in leafy vegetables such as Bayam red [47]. The spirulina-based fertilizers enhanced plants growth in comparison with no fertilization and give similar results than synthetic fertilizers (9.06 gTS for Spirulina sp. vs. $9.52 \mathrm{gTS}$ for synthetic fertilizers) [47]. Castro et al. 2017 studied the effect of algal biomass cultivated in industrial wastewaters on millet crops [46]. Outdoors experiments were conducted in Brazil during 60 days with three different treatments: control (soil), algal biomass and synthetic fertilizer. As a result, the fertilized soils with microalgae improve the biomass yield of $54 \%$ in comparison to the control, in terms of dry biomass (shoot and leaf) obtained per hectare. Furthermore, no significant differences were found between soils fertilized with algal biomass and synthetic fertilizer [46]. Finally, Garcia-Gonzalez and Sommerfeld (2015) also investigated the effect of microalgae (Acutodesmus dimorphus LARB-0414) fertilizers on the tomatoes growth [25]. Microalgae were applied at the transplantation or 22 days prior the transplantation of tomatoes plants. Both configurations improve the tomatoes growth in comparison with the control without fertilization. Nonetheless, applying microalgae 22 days prior transplantation at a concentration of $50 \mathrm{~g}$ lead to an enhancement of the biomass production. Indeed biomass production of $153 \mathrm{~g}$ and $547 \mathrm{~g}$ were respectively noticed for the fertilization at the time of transplant and 22 days prior the time of transplant [25]. 
Table 5. Literature review of microalgae biomass used as fertilizers for plants growth.

\begin{tabular}{|c|c|c|c|c|c|c|c|}
\hline Medium Growth and Pilots Used & $\begin{array}{l}\text { Microalgae Species } \\
\end{array}$ & Crop Type & Fertilizer Application & Cultivation Conditions & $\begin{array}{l}\text { Enhanced Effect of Microalgae Biomass } \\
\text { Grow Rate }\end{array}$ & $\begin{array}{l}\text { ss Treatment Compared to Controls } \\
\text { Leaf Number or Size }\end{array}$ & Ref. \\
\hline \multirow{3}{*}{$\begin{array}{l}\text { Wastewater from aquaculture system. } \\
\text { Microalgae cultivated in outdoor raceway } \\
\text { pond }\left(28 \mathrm{~m}^{2}\right) \text {. }\end{array}$} & \multirow{3}{*}{$\begin{array}{c}\text { Commercial Microalgal } \\
\text { Bacterial flocs }\end{array}$} & \multirow{4}{*}{$\begin{array}{l}\text { Tomato Solanum } \\
\text { lycopersicum cv. }\end{array}$} & (i) liquid inorganic fertilizer, & \multirow{4}{*}{ 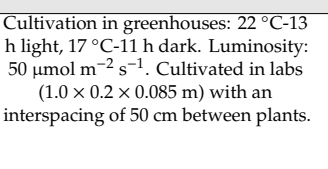 } & \multirow{4}{*}{$\begin{array}{l}\text { (i) } 3.76 \mathrm{~g} \mathrm{TS} \\
\text { (ii) } 3676 \mathrm{~g} \mathrm{TS} \\
\text { (iii) } 4.01 \mathrm{~g} \mathrm{TS} \\
\text { (iv) } 3.83 \mathrm{~g} \mathrm{TS}\end{array}$} & \multirow{4}{*}{$\begin{array}{l}\text { (i) } 40.7 \mathrm{~cm} \\
\text { (ii) } 40.6 \mathrm{~cm} \\
\text { (iii) } 37.8 \mathrm{~cm} \\
\text { (iv) } 42.2 \mathrm{~cm}\end{array}$} & \multirow{4}{*}{ [26] } \\
\hline & & & (ii) solid organic fertilizer, & & & & \\
\hline & & & (iii) MaB-floc fertilizer, & & & & \\
\hline $\begin{array}{l}\text { Modified Guillard's } \mathrm{f} / 2 \text { marine medium. } \\
\text { Microalgae cultivated in outdoor closed flat } \\
\text { panel photobioreactors }\left(25 \mathrm{~m}^{2}\right)\end{array}$ & Nannochloropsis oculata & & (iv) Nannochloropsis fertilizer. & & & & \\
\hline \multirow{11}{*}{$\begin{array}{l}\text { Digestate dairy manure as medium culture. } \\
\text { Algal biomass was produced from } \\
\text { laboratory-scale algal turf scrubbers (ATS) }\end{array}$} & \multirow{11}{*}{ Algal biomass } & \multirow{6}{*}{$\begin{array}{c}\text { Cucumber } \\
\text { (Cucumis satious) }\end{array}$} & (i) $2.8 \mathrm{~g}$ dry alga/pot, & \multirow{11}{*}{$\begin{array}{l}\text { Cultivation in pots located in a } \\
\text { growth chamber. Conditions: } 25^{\circ} \mathrm{C} \\
16 \mathrm{~h} \mathrm{light,} 20^{\circ} \mathrm{C} 8 \mathrm{~h} \text { dark, } 20 \text {-days } \\
\text { growth, } 600 \mu \mathrm{mol} \mathrm{m}^{-2} \mathrm{~s}^{-1} \text {. }\end{array}$} & \multirow{6}{*}{$\begin{array}{l}\text { (i) } 2.98 \mathrm{gTS} / \mathrm{pot} ; \\
\text { (ii) } 3.35 \mathrm{gTS} / \mathrm{pot} ; \\
\text { (iii) } 4.16 \mathrm{gTS} / \mathrm{pot} ; \\
\text { (iv) } 3.18 \mathrm{gTS} / \mathrm{pot} ; \\
\text { (v) } 4.55 \mathrm{gTS} \text { pot; } \\
\text { (vi) } 0.99 \mathrm{gTS} / \mathrm{pot} ;\end{array}$} & \multirow{11}{*}{ - } & \multirow{11}{*}{ [43] } \\
\hline & & & (ii) $5.5 \mathrm{~g} \mathrm{dry}$ alga/pot, & & & & \\
\hline & & & (iii) $11 \mathrm{~g}$ dry alga per pot, & & & & \\
\hline & & & (iv) $1.25 \mathrm{~g}$ indust. fertilizer/pot, & & & & \\
\hline & & & (v) $2.5 \mathrm{~g}$ industrial fertilizer/pot, & & & & \\
\hline & & & (vi) no fertilization. & & & & \\
\hline & & \multirow{5}{*}{ Corn (Zea mays) } & (i) $10 \mathrm{~g}$ dry alga/pot, & & \multirow{5}{*}{$\begin{array}{l}\text { (i) } 6.8 \mathrm{gTS} / \mathrm{pot} ; \\
\text { (ii) } 10.7 \mathrm{gTS} / \mathrm{pot} ; \\
\text { (iii) } 7.7 \mathrm{gTS} / \mathrm{pot} ; \\
\text { (iv) } 8.6 \mathrm{gTS} \text { pot; } \\
\text { (v) } 0.53 \mathrm{gTS} / \mathrm{pot} ;\end{array}$} & & \\
\hline & & & (ii) $20 \mathrm{~g}$ dry alga/pot, & & & & \\
\hline & & & (iii) $5.5 \mathrm{~g}$ indust. fertilizer/ pot, & & & & \\
\hline & & & (iv) $11 \mathrm{~g}$ indust. fertilizer/pot, & & & & \\
\hline & & & (v) no fertilization. & & & & \\
\hline \multirow{5}{*}{$\begin{array}{l}\text { The algal cells were grown at a temperature of } \\
25 \pm 1^{\circ} \mathrm{C} \text { and surface light of about } 2500 \text { lux. }\end{array}$} & \multirow{5}{*}{ Chlorella vulgaris } & \multirow{5}{*}{$\begin{array}{l}\text { Lettuce (lactuca } \\
\text { sativa cv.) }\end{array}$} & (i) no fertilization, & \multirow{5}{*}{$\begin{array}{l}\text { Cultivated in pot in greenhouse } \\
\text { under a } 16 \mathrm{~h} \text { photoperiod at } 20-25^{\circ} \mathrm{C} \\
\text { for } 30 \text { days. }\end{array}$} & \multirow{5}{*}{$\begin{array}{l}\text { (i) } 3.2 \mathrm{gTS} / \text { plant; } \\
\text { (ii) } 5.5 \mathrm{gTS} / \text { plant; } \\
\text { (iii) } 6.5 \mathrm{gTS} / \text { plant; } \\
\text { (iv) } 8.3 \mathrm{gTS} / \text { lant; } \\
\text { (v) } 9.8 \mathrm{gTS} / \text { plant; }\end{array}$} & \multirow{5}{*}{ - } & \multirow{5}{*}{ [24] } \\
\hline & & & (ii) $1 / 2 \mathrm{~g} / \mathrm{kg}$ of soil of dry algae, & & & & \\
\hline & & & (iii) $1 \mathrm{~g} / \mathrm{kg}$ of soil of dry algae, & & & & \\
\hline & & & (iv) $2 \mathrm{~g} / \mathrm{kg}$ of soil of dry algae, & & & & \\
\hline & & & (v) $3 \mathrm{~g} / \mathrm{kg}$ of soil of dry algae. & & & & \\
\hline \multirow{4}{*}{$\begin{array}{l}\text { Fish wastewater. Batch cultivation }(2 \mathrm{~L}) \text { of the } \\
\text { microalgae was performed using the obtained } \\
\text { fish water in glass bottles and air-aerated with } \\
\text { aflow rate of } 10-15 \mathrm{~mL} / \mathrm{min} \text { at } 28-30^{\circ} \mathrm{C} \text {. }\end{array}$} & \multirow{4}{*}{ S. platensis (LB 1928) } & \multirow{2}{*}{$\begin{array}{c}\text { Arugula } \\
\text { (Erucasativa) }\end{array}$} & (i) no fertilization, & \multirow{4}{*}{ 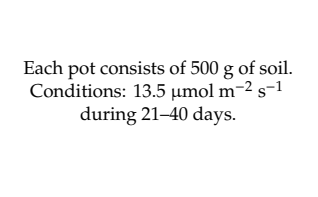 } & $\begin{array}{l}\text { (i) } 4.28 \mathrm{gTS} \text {; } \\
\text { (ii) } 10.95 \mathrm{gTS} ; \\
\text { (iii) } 21.16 \mathrm{gTS} \text {; }\end{array}$ & \multirow{2}{*}{$\begin{array}{l}\text { (i) } 9.3 \text { leaves } \\
\text { (ii) } 11 \text { leaves } \\
\text { (iii) } 12.3 \text { leaves } \\
\text { (iv) } 13.3 \text { leaves } \\
\end{array}$} & \multirow{4}{*}{ [27] } \\
\hline & & & (ii) Spirulina ( $5 \mathrm{~g} / \mathrm{pot})$, & & (iv) 22.74 gTS & & \\
\hline & & \multirow{2}{*}{$\begin{array}{l}\text { Bayam Red } \\
\text { (Ameranthus } \\
\text { gangeticus), }\end{array}$} & (iii) chemical fertilizer, & & (i) $7.48 \mathrm{gTS}$; & \multirow{2}{*}{$\begin{array}{l}\text { (i) }) .6 \text { leaves } \\
\text { (ii) leaves } \\
\text { (iii) } 9.7 \text { leaves } \\
\text { (iv) } 9.7 \text { leaves }\end{array}$} & \\
\hline & & & $\begin{array}{l}\text { (iv) Spirulina }(5 \mathrm{~g} / \mathrm{pot}) \text { plus chemical } \\
\text { fertilizer. }\end{array}$ & & $\begin{array}{l}\text { (ii) } 9.06 \text { gTS; } \\
\text { (iii) } 9.52 \text { gTS; } \\
\text { (iv) } 10 \text { gTS: }\end{array}$ & & \\
\hline
\end{tabular}


Table 5. Cont

\begin{tabular}{|c|c|c|c|c|c|c|c|}
\hline Medium Growth and Pilots Used & Microalgae Species & Crop Type & Fertilizer Application & Cultivation Conditions & $\begin{array}{l}\text { Enhanced Effect of Microalgae Bi } \\
\text { Grow Rate }\end{array}$ & $\begin{array}{l}\text { ass Treatment Compared to Controls } \\
\text { Leaf Number or Size }\end{array}$ & Ref. \\
\hline \multirow{5}{*}{$\begin{array}{l}\text { BG } 11 \text { medium. Cultivated in } 1 \mathrm{~L} \text { conical flasks } \\
\text { by continuous air bubbling under continuous } \\
\text { illumination } 3500 \text { lux for } 7 \text { days }\end{array}$} & \multirow{5}{*}{ Chlorella oocystoides } & \multirow{5}{*}{ Zea mays } & (i) Without algae (Control 0\%), & \multirow{5}{*}{$\begin{array}{l}\text { Black plastic pots }(15 \mathrm{~cm} \text { in diameter } \\
\text { and } 20 \mathrm{~cm} \text { height). }\end{array}$} & \multirow{5}{*}{$\begin{array}{l}\text { (i) } 0.98 \mathrm{gTS} / \text { plant } \\
\text { (ii) } 1.03 \mathrm{gTS} / \mathrm{plant} \\
\text { (iii) } 1.33 \mathrm{gTS} / \mathrm{plant} \\
\text { (iv) } 1.5 \mathrm{gTS} / \mathrm{lant} \\
\text { (v) } 1.49 \mathrm{gTS} / \mathrm{plant}\end{array}$} & \multirow{5}{*}{$\begin{array}{l}\text { (i) 6 leaves } \\
\text { (ii) } 6.1 \text { leaves } \\
\text { (iii) } 6.5 \text { leaves } \\
\text { (iv) } 6.7 \text { leaves } \\
\text { (v) } 6.5 \text { leaves }\end{array}$} & \multirow{5}{*}{ [47] } \\
\hline & & & (ii) $0.1 \%$ of algae, & & & & \\
\hline & & & (iii) $1 \%$ of algae, & & & & \\
\hline & & & (iv) $2.5 \%$ of algae, & & & & \\
\hline & & & (v) $5 \%$ of algae. & & & & \\
\hline \multirow{3}{*}{$\begin{array}{l}\text { Industrial wastewater from meat processing } \\
\text { industry. Microalgae cultivated in a high-rate } \\
\text { algal pond (HRAP) }\end{array}$} & \multirow{3}{*}{$\begin{array}{l}\text { Consortium of algal } \\
\text { biomass }\end{array}$} & \multirow{3}{*}{$\begin{array}{l}\text { Millet crop, } \\
\text { Pennisetum } \\
\text { glaucum, (BRS } \\
1501 \text { cultivar) }\end{array}$} & (i) no fertilization, & \multirow{3}{*}{$\begin{array}{l}\text { Outdoors Brazil; plot of } 4 \mathrm{~m}^{2} . \\
\text { Duration: } 60 \text { days. }\end{array}$} & \multirow{3}{*}{$\begin{array}{l}\text { (i) } 2933 \mathrm{kgTS} \mathrm{ha}^{-1} \\
\text { (ii) } 4523 \mathrm{kgTS} \mathrm{ha}^{-1} \\
\text { (iii) } 4979 \mathrm{kgSS} \mathrm{ha}^{-1}\end{array}$} & \multirow{3}{*}{$\begin{array}{l}\text { 4-30\%. No significant difference with } \\
\text { industrial fertilizers }\end{array}$} & \multirow{3}{*}{ [25] } \\
\hline & & & $\begin{array}{l}\text { (ii) } 120 \mathrm{~kg} \mathrm{ha}^{-1} \text { of N provided by the } \\
\text { algal biomass, }\end{array}$ & & & & \\
\hline & & & $\begin{array}{l}\text { (iii) } 120 \mathrm{~kg} \mathrm{ha}^{-1} \text { of N provided by } \\
\text { conventional urea. }\end{array}$ & & & & \\
\hline \multirow{6}{*}{$\begin{array}{l}\text { BG11 algae culture medium. Microalgae } \\
\text { cultivated outdoors in seven } 1.22 \mathrm{~m} \times 14.63 \mathrm{~m} \\
\text { production row panel photobioreactors }\end{array}$} & \multirow{6}{*}{$\begin{array}{l}\text { Acutodesmus dimorphus } \\
\text { (LARB-0414) }\end{array}$} & \multirow{6}{*}{$\begin{array}{l}\text { Roma tomato }(\mathrm{S} \text {. } \\
\text { lycopersicum var. } \\
\text { Roma) seeds }\end{array}$} & (i) control (no fertilizers), & \multirow{6}{*}{$\begin{array}{l}28^{\circ} \mathrm{C}, 85 \% \text { humidity, greenhouse, } 14 \\
\text { days growth. The seedlings were } \\
\text { grown into } 28 \text {-cm pots for } 8 \text { weeks. }\end{array}$} & \multirow{3}{*}{$\begin{array}{l}\text { (i) } 47 \mathrm{~g} \text { (weight of shoot and root) } \\
\text { (ii) } 13 \mathrm{~g} \text { (B1) } \\
\text { (iii) } 70.5 \mathrm{~g} \text { (B2) }\end{array}$} & \multirow{3}{*}{$\begin{array}{l}53 \% \text { with } 50 \mathrm{~g} \text { of biofertilizer } \\
88 \% \text { with } 100 \mathrm{~g} \text { of biofertilizer }\end{array}$} & \multirow{6}{*}{ [46] } \\
\hline & & & $\begin{array}{l}\text { (ii) } 50 \mathrm{~g} \text { of biofertilizer applied at the } \\
\text { time of transplant (B1), }\end{array}$ & & & & \\
\hline & & & $\begin{array}{l}\text { (iii) } 100 \mathrm{~g} \text { of biofertilizer applied at } \\
\text { the time of transplant (B22). }\end{array}$ & & & & \\
\hline & & & (i) control (no fertilizers), & & \multirow{3}{*}{$\begin{array}{l}\text { (i) } 47 \mathrm{~g} \text { (weight of shoot and root) } \\
\text { (ii) } 547 \mathrm{~g}(\mathrm{B1}) \\
\text { (iii) } 564 \mathrm{~g}(\mathrm{B2})\end{array}$} & \multirow{3}{*}{$\begin{array}{l}123 \% \text { with } 50 \mathrm{~g} \text { of biofertilizer } \\
192 \% \text { with } 100 \mathrm{~g} \text { of biofertilizer }\end{array}$} & \\
\hline & & & $\begin{array}{l}\text { (ii) } 50 \mathrm{~g} \text { of biofertilizer applied } 22 \\
\text { days prior to transplant }(\mathrm{B} 1) \text {, }\end{array}$ & & & & \\
\hline & & & $\begin{array}{l}\text { (iii) } 100 \mathrm{~g} \text { of biofertilizer applied } 22 \\
\text { days prior to transplant (B2). }\end{array}$ & & & & \\
\hline $\begin{array}{l}\text { Agricultural liquid digestate diluted at 1:50. } \\
\text { Microalgae cultivated in outdoor condition in } \\
110 \mathrm{~L} \text { photobioreactors }\end{array}$ & Monoraphidium sp. & $\begin{array}{c}\text { tomatoes } \\
\text { (Solanum } \\
\text { Lycopersicum) }\end{array}$ & $\begin{array}{l}\text { (i) no fertilizers, } \\
\text { (ii) industrial fertilizers } 170 \mathrm{kgN} / \mathrm{ha}, \\
\text { (iii) liquid digestate } 170 \mathrm{~kg} \mathrm{~N} / \mathrm{ha}, \\
\text { (iv) microalgae at } 70 \mathrm{~kg} \mathrm{~N} / \mathrm{ha} \text {. }\end{array}$ & $\begin{array}{l}\text { Cultivation in } 0.5 \mathrm{~L} \text { pot in growth } \\
\text { chamber. During the trial, the } \\
\text { environmental conditions were the } \\
\text { following ones: day duration } 16 \mathrm{~h} \text { at } \\
25^{\circ} \mathrm{C} \text { under } 4600 \text { lux }\left(62.1 \mu \mathrm{mol} \mathrm{m} \mathrm{m}^{2}\right. \\
\left.\mathrm{s}^{-1}\right) \text {, in } 60 \% \text { relative humidity, } \\
\text { whereas night conditions were } 8 \mathrm{~h} \\
\text { darkness at } 18^{\circ} \mathrm{C} \text { in } 80 \% \\
\text { relative humidity. }\end{array}$ & $\begin{array}{l}\text { (i) } 19.4 \mathrm{gTS} / 100 \text { plants } \\
\text { (ii) } 24.8 \mathrm{gTS} / 100 \text { plants } \\
\text { (iii) } 25.2 \mathrm{gST} / 100 \text { plants } \\
\text { (iv) } 25.7 \mathrm{gTS} / 100 \text { plants }\end{array}$ & $\begin{array}{l}\text { (i) } 20.8 \text { leaves/ plant } \\
\text { (ii) } 30 \text { leaves/ plant } \\
\text { (iii) } 2.6 \text { leaves/ plant } \\
\text { (iv) } 27.4 \text { leaves/ plant }\end{array}$ & This work \\
\hline
\end{tabular}


According to many authors [26,46,47], even growing plants with microalgae biomass wasn't better than those grown with synthetic fertilizers or digestate, the use of microalgal biomass for fertilizing purposes presents some important advantages. Microalgal biomass can be considered as a slow-released fertilizer since the application of dried biomass to soils would not result in emissions nitrous oxide and ammonia volatilization, as is the case of digestates [7,46]. Microalgae biomass presents other advantages over synthetic fertilizers because it is not as pollutant as synthetic fertilizers and microalgae cultivation contributes to the upgrading of the liquid digestate phases without losing fertilizers properties.

In parallel, to assess the benefits of using microalgae fertilizers against synthetic fertilizers or liquid digestate as a way to reduce nutrients leaching, the effect of the three fertilization methods (at $170 \mathrm{~kg} \mathrm{~N} / \mathrm{ha}$ ) was studied using nutrients leaching columns to understand the $\mathrm{N}\left(\mathrm{NH}_{4}{ }^{+}, \mathrm{NO}_{2}{ }^{-}\right.$and $\mathrm{NO}_{3}{ }^{-}$) leaching once applied the fertilizers in soil. This study was intended to represent a worst-case scenario with extremely heavy rainfall just after adding the different fertilizers. During the 25 days of experiment, similar leachate volumes were recovered from all soil columns (around $18 \mathrm{~mL}$ per leaching event). As shown in Figure 5, the soil amended with synthetic fertilizer presented a major loss of $\mathrm{N}$. Interestingly, with microalgae fertilization, only $7 \%$ of $\mathrm{N}$ was leached, compared to $50 \%$ in the case of synthetic fertilizer and $24 \%$ for the liquid digestate.

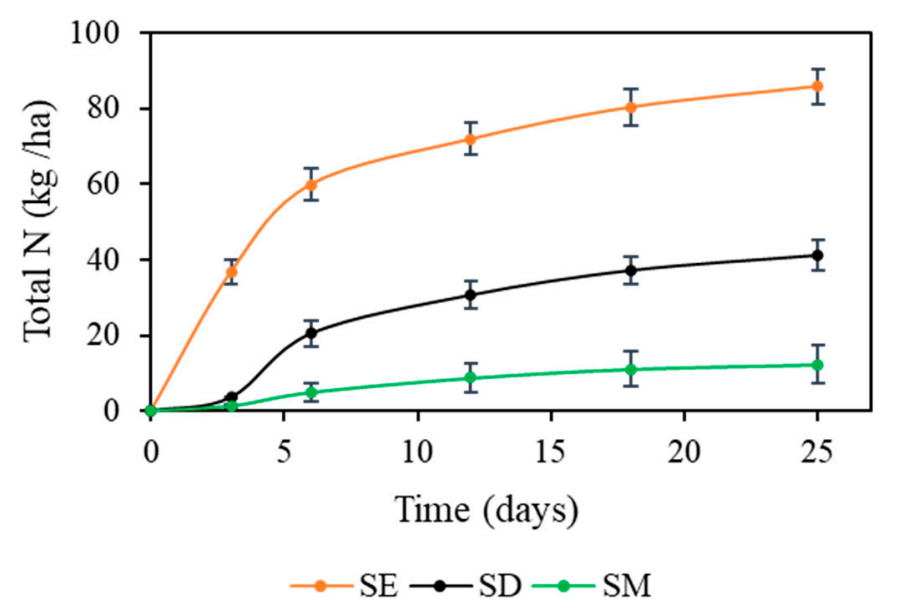

Figure 5. Cumulative leached amount of $\mathrm{NH}_{4}{ }^{+}-\mathrm{N}, \mathrm{NO}_{3}{ }^{-}-\mathrm{N}, \mathrm{NO}_{2}{ }^{-}-\mathrm{N}(\mathrm{kg} \mathrm{N} / \mathrm{ha})$ in soil treated with synthetic fertilizer (SE), liquid digestate (SD) and microalgae biomass (SM). For each condition, the lixiviation due to the control (soil alone) have been subtracted.

The results showed that microalgal biomass retains $\mathrm{N}$ better and release it slowly. This slow-releasing nature can be explained because $\mathrm{N}$ is in the organic form in microalgal biomass that need to be mineralized to be leached in the mineral form [26]. Sogn et al. (2018) also performed leaching nutrients during seven days in columns without plant growth on industrial fertilizers and several digestates on various soils (i.e., loam, sand, slit) [33]. Industrial fertilizers lead to similar nutrients leaching than the present study with $19 \%-41 \%$ of $\mathrm{N}$ leached according to the soil origin, with lower leaching observed in silt soil. For all the digestates investigated the nutrient leaching ranged from $17 \%$ to $52 \%$ which is in agreement with the present results [33]. Nonetheless, such results have to be considered as preliminary assay and should be repeated in pilot lysimeter simulating simultaneous plant growth or just after the harvest period as the $\mathrm{N}$ dynamic and loses will not be the same. Furthermore, nutrient leaching potential following application of fertilizers depends on several others factors such as fertilization strategies (e.g., time and methods of application), soil texture (e.g., sand, silt, loam soils), topography, precipitations and cropping systems [9]. 


\section{Conclusions}

In this study, it was demonstrated that microalgae can efficiently remove the nutrients from digestate once the best dilution factor applied. Outdoors photo-bioreactors reached $100 \%$ of $\mathrm{NH}_{4}{ }^{+}$ removal and an average of $64.77 \%$ for $\mathrm{PO}_{4}^{-3}$ removal. In addition, the microalgal biomass produced ( $38.3 \mathrm{mgTSS} \mathrm{L}^{-1} \mathrm{~d}^{-1}$ ) has proved to enhance tomato plants growth by $32 \%$ (plant dry biomass) with $32 \%$ more leaves and $12 \%$ higher content in chlorophyll a, compared to control tests (without fertilizers). The leaching behavior was also improved by the addition of microalgae biomass, finding a notable different with the leaching effect in case of synthetic fertilizer. After 25 days, only $7 \%$ of total $\mathrm{N}$ was leached when adding microalgae biomass to soil, versus $50 \%$ leached when synthetic fertilizer was used.

Supplementary Materials: The following are available online at http://www.mdpi.com/2076-3417/10/11/3890/s1, Figure S1: Cultivation of Monoraphidium sp. in batch at different concentrations, from left to right 1:20, 1:30, 1:50 respectively; Figure S2: Cultivation of Monoraphidium sp. in photobioreactors of $110 \mathrm{dm}^{3}$ in batch/semi-continuous regimes with digestate diluted at 1:50.

Author Contributions: R.J.: Investigation, methodology, data curation, writing-review; G.M.: writing—review and editing; A.B.: writing-review and editing; C.C.: Investigation, methodology, conceptualization, data curation; S.T.: methodology, data curation; F.M.: conceptualization, data curation, writing-review and editing, project administration, supervision. All authors have read and agreed to the published version of the manuscript.

Funding: This research was funded by Nouvelle Aquitaine region (FRANCE), grant number 19R04.

Acknowledgments: We are grateful to the Nouvelle Aquitaine region for its financial support through the FEDER program, which allow us to perform this assay.

Conflicts of Interest: The authors declare no conflict of interest. The funders had no role in the design of the study; in the collection, analyses, or interpretation of data; in the writing of the manuscript, or in the decision to publish the results.

\section{Abbreviations}

The following abbreviations are used in this manuscript:

$\begin{array}{ll}\text { AD } & \text { Anaerobic digestion } \\ \text { Ca } & \text { Carotenoids } \\ \text { Ch.a } & \text { Chlorophyll a } \\ \text { Ch.b } & \text { Chlorophyll b } \\ \text { CHP } & \text { Cogeneration Heat and Power system } \\ \text { OFMSW } & \text { Organic Fraction of Municipal Solid Wastes } \\ \text { TS } & \text { Total Solids } \\ \text { TSS } & \text { Total Solids Suspended } \\ \text { VS } & \text { Volatile Solids }\end{array}$

\section{References}

1. Carrere, H.; Antonopoulou, G.; Affes, R.; Passos, F.; Battimelli, A.; Lyberatos, G.; Ferrer, I. Review of feedstock pretreatment strategies for improved anaerobic digestion: From lab-scale research to full-scale application. Bioresour. Technol. 2016, 199, 386-397. [CrossRef]

2. Elalami, D.; Carrere, H.; Monlau, F.; Abdelouahdi, K.; Oukarroum, A.; Barakat, A. Pretreatment and co-digestion of wastewater sludge for biogas production: Recent research advances and trends. Renew. Sustain. Energy Rev. 2019, 114, 109287. [CrossRef]

3. Alburquerque, J.A.; de la Fuente, C.; Costa, A.F.; Carrasco, L.; Cegarra, J.; Abad, M.; Bernal, M.P. Assessment of the fertiliser potential of digestates from farm and agroindustrial residues. Biomass Bioenergy 2012, 40, 181-189. [CrossRef]

4. Monlau, F.; Sambusiti, C.; Ficara, E.; Aboulkas, A.; Barakat, A.; Carrère, H. New opportunities for agricultural digestate valorization: Current situation and perspectives. Energy Environ. Sci. 2015, 8, 2600-2621. [CrossRef]

5. Tambone, F.; Genevini, P.; D’Imporzano, G.; Adani, F. Assessing amendment properties of digestate by studying the organic matter composition and the degree of biological stability during the anaerobic digestion of the organic fraction of msw. Bioresour. Technol. 2009, 100, 3140-3142. [CrossRef] 
6. Akhiar, A.; Battimelli, A.; Torrijos, M.; Carrere, H. Comprehensive characterization of the liquid fraction of digestates from full-scale anaerobic co-digestion. Waste Manag. 2017, 59, 118-128. [CrossRef]

7. Baral, K.R.; Jégo, G.; Amon, B.; Bol, R.; Chantigny, M.H.; Olesen, J.E.; Petersen, S.O. Greenhouse gas emissions during storage of manure and digestates: Key role of methane for prediction and mitigation. Agric. Syst. 2018, 166, 26-35. [CrossRef]

8. Jiang, Y.; Pu, X.; Zheng, D.; Zhu, T.; Wang, S.; Deng, L.; Wang, W. Cultivation of lipid-producing microalgae in struvite-precipitated liquid digestate for biodiesel production. Biotechnol. Biofuels 2018, 11. [CrossRef]

9. Nkoa, R. Agricultural benefits and environmental risks of soil fertilization with anaerobic digestates: a review. Agron. Sustain. Dev. 2013, 34, 473-492. [CrossRef]

10. Sheets, J.P.; Yang, L.; Ge, X.; Wang, Z.; Li, Y. Beyond land application: Emerging technologies for the treatment and reuse of anaerobically digested agricultural and food waste. Waste Manag. 2015, 44, 94-115. [CrossRef]

11. Xia, A.; Murphy, J.D. Microalgal cultivation in treating liquid digestate from biogas systems. Trends Biotechnol. 2016, 34, 264-275. [CrossRef] [PubMed]

12. Franchino, M.; Comino, E.; Bona, F.; Riggio, V.A. Growth of three microalgae strains and nutrient removal from an agro-zootechnical digestate. Chemosphere 2013, 92, 738-744. [CrossRef] [PubMed]

13. Zuliani, L.; Frison, N.; Jelic, A.; Fatone, F.; Bolzonella, D.; Ballottari, M. Microalgae cultivation on anaerobic digestate of municipal wastewater, sewage sludge and agro-waste. Int. J. Mol. Sci. 2016, 17, 1692. [CrossRef]

14. Delrue, F.; Álvarez-Díaz, P.; Fon-Sing, S.; Fleury, G.; Sassi, J.-F. The environmental biorefinery: Using microalgae to remediate wastewater, a win-win paradigm. Energies 2016, 9, 132. [CrossRef]

15. Marazzi, F.; Sambusiti, C.; Monlau, F.; Cecere, S.E.; Scaglione, D.; Barakat, A.; Mezzanotte, V.; Ficara, E. a novel option for reducing the optical density of liquid digestate to achieve a more productive microalgal culturing. Algal Res. 2017, 24, 19-28. [CrossRef]

16. Markou, G.; Monlau, F. Nutrient recycling for sustainable production of algal biofuels. Biomassbiofuels Biochem. 2019, 6, 109-133.

17. Markou, G.; Wang, L.; Ye, J.; Unc, A. Using agro-industrial wastes for the cultivation of microalgae and duckweeds: Contamination risks and biomass safety concerns. Biotechnol. Adv. 2018, 36, 1238-1254. [CrossRef]

18. Markou, G.; Wang, L.; Ye, J.; Unc, A. Cultivation of microalgae on anaerobically digested agro-industrial wastes and by-products. In Application of Microalgae in Wastewater Treatment; Springer Nature: Cham, Switzerland, 2020; pp. 1-29.

19. Li, J.; Wang, L.; Lu, Q.; Zhou, W. Toxicity alleviation for microalgae cultivation by cationic starch addition and ammonia stripping and study on the cost assessment. Rsc Adv. 2019, 9, 38235-38245. [CrossRef]

20. Voloshin, R.A.; Rodionova, M.V.; Zharmukhamedov, S.K.; Nejat Veziroglu, T.; Allakhverdiev, S.I. Review: Biofuel production from plant and algal biomass. Int. J. Hydrog. Energy 2016, 41, 17257-17273. [CrossRef]

21. Ayre, J.M.; Moheimani, N.R.; Borowitzka, M.A. Growth of microalgae on undiluted anaerobic digestate of piggery effluent with high ammonium concentrations. Algal Res. 2017, 24, 218-226. [CrossRef]

22. Uysal, O.; Uysal, F.O.; Ekinci, K. Evaluation of microalgae as microbial fertilizer. Eur. J. Sustain. Dev. 2015, 4, 77-82. [CrossRef]

23. Ronga, D.; Biazzi, E.; Parati, K.; Carminati, D.; Carminati, E.; Tava, A. Microalgal biostimulants and biofertilisers in crop productions. Agronomy 2019, 9, 192. [CrossRef]

24. Faheed, F.A.; Abd-El Fattah, Z. Effect of chlorella vulgaris as bio-fertilizer on growth parameters and metabolic aspects of lettuce plant. J. Agri. Soc. Sci. 2008, 4, 165-169.

25. Garcia-Gonzalez, J.; Sommerfeld, M. Biofertilizer and biostimulant properties of the microalga acutodesmus dimorphus. J. Appl. Phycol. 2015, 28, 1051-1061. [CrossRef] [PubMed]

26. Mulbry, W.; Westhead, E.K.; Pizarro, C.; Sikora, L. Recycling of manure nutrients: Use of algal biomass from dairy manure treatment as a slow release fertilizer. Bioresour. Technol. 2005, 96, 451-458. [CrossRef] [PubMed]

27. Taha, T.M.; Youssef, M.A. Improvement of growth parameters of zea mays and properties of soil inoculated with two chlorella species. Rep. Opin. 2015, 7, 22-27.

28. El-Sharony, T.F.; El-Gioushy, S.F.; Amin, O.A. Effect of foliar application with algae and plant extracts on growth, yield and fruit quality of fruitful mango trees cv. Fagri kalan. J. Hortic. 2015, 2. [CrossRef]

29. Dineshkumar, R.; Kumaravel, R.; Gopalsamy, J.; Sikder, M.N.A.; Sampathkumar, P. Microalgae as bio-fertilizers for rice growth and seed yield productivity. Waste Biomass Valorization 2017, 9, 793-800. [CrossRef] 
30. Gell, K.; van Groenigen, J.; Cayuela, M.L. Residues of bioenergy production chains as soil amendments: Immediate and temporal phytotoxicity. J. Hazard. Mater. 2011, 186, 2017-2025. [CrossRef]

31. Sumanta, N.; Haque, C.I.; Nishika, J.; Suprakash, R. Spectrophotometric analysis of chlorophylls and carotenoids from commonly grown fern species by using various extracting solvents. Res. J. Chem. Sci. 2014, 4, 63-69.

32. Laird, D.; Fleming, P.; Wang, B.; Horton, R.; Karlen, D. Biochar impact on nutrient leaching from a midwestern agricultural soil. Geoderma 2010, 158, 436-442. [CrossRef]

33. Sogn, T.A.; Dragicevic, I.; Linjordet, R.; Krogstad, T.; Eijsink, V.G.H.; Eich-Greatorex, S. Recycling of biogas digestates in plant production: Npk fertilizer value and risk of leaching. Int. J. Recycl. Org. Waste Agric. 2018, 7, 49-58. [CrossRef]

34. Dhup, S.; Dhawan, V. Effect of nitrogen concentration on lipid productivity and fatty acid composition of monoraphidium sp. Bioresour. Technol. 2014, 152, 572-575. [CrossRef] [PubMed]

35. Uggetti, E.; Sialve, B.; Latrille, E.; Steyer, J.-P. Anaerobic digestate as substrate for microalgae culture: The role of ammonium concentration on the microalgae productivity. Bioresour. Technol. 2014, 152, 437-443. [CrossRef] [PubMed]

36. Prajapati, S.K.; Kumar, P.; Malik, A.; Vijay, V.K. Bioconversion of algae to methane and subsequent utilization of digestate for algae cultivation: a closed loop bioenergy generation process. Bioresour. Technol. 2014, 158, 174-180. [CrossRef] [PubMed]

37. Masojídek, J.; Torzillo, G. Mass Cultivation of Freshwater Microalgae; Elsevier: Amsterdam, The Netherlands, 2008; pp. 2226-2235.

38. Marcilhac, C.; Sialve, B.; Pourcher, A.-M.; Ziebal, C.; Bernet, N.; Béline, F. Digestate color and light intensity affect nutrient removal and competition phenomena in a microalgal-bacterial ecosystem. Water Res. 2014, 64, $278-287$. [CrossRef]

39. Marín, D.; Posadas, E.; Cano, P.; Pérez, V.; Blanco, S.; Lebrero, R.; Muñoz, R. Seasonal variation of biogas upgrading coupled with digestate treatment in an outdoors pilot scale algal-bacterial photobioreactor. Bioresour. Technol. 2018, 263, 58-66. [CrossRef]

40. Řezanka, T.; Nedbalová, L.; Lukavský, J.; Stř́žek, A.; Sigler, K. Pilot cultivation of the green alga monoraphidium sp. Producing a high content of polyunsaturated fatty acids in a low-temperature environment. Algal Res. 2017, 22, 160-165.

41. Barreiro-Vescovo, S.; Barbera, E.; Bertucco, A.; Sforza, E. Integration of microalgae cultivation in a biogas production process from organic municipal solid waste: From laboratory to pilot scale. ChemEngineering 2020, 4, 25. [CrossRef]

42. Ruiz, J.; Arbib, Z.; Álvarez-Díaz, P.D.; Garrido-Pérez, C.; Barragán, J.; Perales, J.A. Photobiotreatment model (phbt): a kinetic model for microalgae biomass growth and nutrient removal in wastewater. Environ. Technol. 2013, 34, 979-991. [CrossRef]

43. Coppens, J.; Grunert, O.; Van Den Hende, S.; Vanhoutte, I.; Boon, N.; Haesaert, G.; De Gelder, L. The use of microalgae as a high-value organic slow-release fertilizer results in tomatoes with increased carotenoid and sugar levels. J. Appl. Phycol. 2015, 28, 2367-2377. [CrossRef]

44. Da Ros, C.; Libralato, G.; Ghirardini, A.V.; Radaelli, M.; Cavinato, C. Assessing the potential phytotoxicity of digestate from winery wastes. Ecotoxicol. Environ. Saf. 2018, 150, 26-33. [CrossRef] [PubMed]

45. Solé-Bundó, M.; Cucina, M.; Folch, M.; Tàpias, J.; Gigliotti, G.; Garfí, M.; Ferrer, I. Assessing the agricultural reuse of the digestate from microalgae anaerobic digestion and co-digestion with sewage sludge. Sci. Total Environ. 2017, 586, 1-9. [CrossRef] [PubMed]

46. Castro, J.D.S.; Calijuri, M.L.; Assemany, P.P.; Cecon, P.R.; de Assis, I.R.; Ribeiro, V.J. Microalgae biofilm in soil: Greenhouse gas emissions, ammonia volatilization and plant growth. Sci. Total Environ. 2017, 574, 1640-1648. [CrossRef]

47. Wuang, S.C.; Khin, M.C.; Chua, P.Q.D.; Luo, Y.D. Use of spirulina biomass produced from treatment of aquaculture wastewater as agricultural fertilizers. Algal Res. 2016, 15, 59-64. [CrossRef]

(C) 2020 by the authors. Licensee MDPI, Basel, Switzerland. This article is an open access article distributed under the terms and conditions of the Creative Commons Attribution (CC BY) license (http://creativecommons.org/licenses/by/4.0/). 